\title{
Trade Liberalization and Employment Performance of Textile and Clothing Industry in Tanzania
}

\author{
Wumi K. Olayiwola (Corresponding author) \\ Department of Economics and Development Studies \\ College of Development Studies, Covenant University, Ota, Nigeria \\ Tel: 234-80-5470-1213Ｅ-mail: kolayiwola@gmail.com \\ Johansein Ladislaus Rutaihwa \\ Economist, Ministry of Industry, Trade and Marketing \\ NSSF Waterfront House, Dar es salaam, Tanzania \\ Tel: 255-75-454-5718Ｅ-mail: johansein@gmail.com
}

\begin{abstract}
The objective of this study is to investigate the effect of trade liberalization on employment performance of textile industry in Tanzania. The basic issue of concern is that the implementation of trade liberalization has differential impact on employment and wage in many African countries. In addressing this issue as well as achieving the objective, econometric models of employment and wage are estimated using co-integration method of analysis. The analysis shows that effective rate of protection and export intensity have an insignificant positive impact on demand for labour, but import penetration has a significant negative impact on employment. Also, only import penetration has a significant negative impact on wage. The impact of import penetration is larger than that of export orientation, as the increase in import competition leads to a decline in labour demand. These findings point to the fact that to make trade liberalization to be effectual in Tanzania, the process of trade reform needs to be gradual and also need to be strengthened with appropriate institutional support.
\end{abstract}

Keywords: Employment, Trade Liberalization, Textiles and Wages

JEL: C22, E24, F13, J31, L67

\section{Introduction}

The study investigates the issue of trade liberalization and employment performance in the textile and clothing industry in Tanzania. Furusawa (1999) states that trade liberalization increases the incidence of poverty, unemployment, job security, and social inequalities. However evidence from countries like India, Mexico, India, Russia and Tunisia indicates that trade liberalization has not negatively affect the manufacturing sector but instead increases the performance of industries in these countries.

Tanzania is one of the African countries that implemented economic reforms in the mid 1980s. The country implemented Structural Adjustment Programme (SAP) under the tutelage of the International Monetary Fund/World Bank since the mid 1980s, but the tempo of liberalization and SAP picked up from the mid 1990s (Mkenda, 2005). The government decision to liberalise trade and investment policies witnessed a number of challenges. Many companies were closed down in the 1980s as they could not withstand competition from imported textiles. For example, in the early 1980s there was a reduction of number of textile firms from 35 to 2 in 1996 (Mkenda, 2005). The sector also suffers serious constraints leading to under utilization of local cotton product and reduction in employment creation or income generating opportunities. These reforms have impact on the labour market in terms of employment and income. Thus, understanding the way in which employment has been affected by trade liberalization is crucial, especially with respect to income generating activities of people and its implications on poverty, welfare and standard of living.

The eroded purchasing power made textile consumption to fall and also resulted to increase in the cost of production. The effect also had an impact on cotton production, whereby the declining cotton consumption reduces its production due to high cost. These developments in Tanzania therefore raise one major research question. What are the transmission mechanisms of linking trade liberalization to employment and wages. In addressing this question, cointegration method of analysis is employed. The results of the analysis show that in the long-run, export intensity and import penetration affects demand of labour in the industry. However, the impact of import 
penetration is stronger than that of export orientation, as the increase in import competition leads to decline in labour demand. It further shows that there has been a very low increase of wages during the period of liberalization. This implies that, in the short run, labour is paid less and remains poor and therefore becomes victims of trade reform and hence is likely to remain poor. The rest part of the paper is arranged as follows. Section two covers the review of the literature, while section three presents the theoretical models. Section four deals with data sources and empirical results and the last section covers summary and conclusion.

\section{Literature Survey}

The adoption of trade reforms is a complex issue that cannot be explained by a single school of thought. One of the basic arguments that Matusz and Tarr (1999) agree to in terms of trade reforms is that a regime of liberal trade leads to a more efficient allocation of resources and higher level of economic well being than a regime involving artificial distortions of trade. Thus, there is a need to differentiate between net adjustment costs and gross adjustment costs. The increase of gross adjustment costs reflect the rise in turnover cost of resources while net adjustment costs rise following changes in capital and labour. Furusawa (1999) analysis shows that trade reforms lead to changes in demand and tastes, technology change, natural conditions, regulatory changes and political instability or changes in international agreements, such as trade agreements. Hitherto, there is no any consensus on the definition of adjustment costs, but there exists a consensus that adjustment costs can be defined as both short run and long run effects which involves the transfer of resources from one sector to another. Adjustment costs are borne by both the public and private sector thus its burden can be felt at an individual or public level.

Occurrence of adjustment costs is associated with number of indicators. These indicators are reduction in employment and output, job displacement, personal costs, retraining costs and forgone earnings. They also include the loss of industry-specific and firm-specific human capital, and macroeconomic instability resulting from balance of payments difficulties or reductions in government revenue and loss of preference margin. However the adjustment costs in labour market can be accelerated by factors such as the degree of governmental support for unemployed workers, the demographics of the population, the distribution of skills, the share of economic activity undertaken by state-owned enterprises, laws restricting involuntary separations and the degree of unionization (Rutaihwa and Olayiwola 2010).

Theoretical linkages of trade liberalization and labour market are well documented in the literature. de Corboda and Serena (2004) model relies on the assumption that the economy is divided into three sectors, exportable, importable and non-tradable sectors and each sector is labeled with its price. The model explains this link by comparing two time-spans, the short run and the long run. In the short run the fixed capital amount of each sector is assumed to be specific to each sector, hence leading to an upward sloping supply curve under conventional assumptions. The prices of exportable and importable goods are determined by the world prices at the going exchange rate while prices for the importable sector are determined endogenously by domestic demand and supply. The model also looks on the state of technology which assumes the labour force and level of technology of a given sector is fixed. In their study of labour market demand and adjustment costs, they added another assumption which is the ranking in descending order of labour intensity in exports, non-tradables and imports.

According to de Melo and Tarr (1990), the worsening terms of trade leads to a diversification of production from exportable to importable sector. This is also associated with the movement of labour and capital stock from the sector. The real wage in exportable sector rise while in importable sector and the real product wage declines. The net effect on employment in the non-tradable sector is open to discussion under this circumstance because it may rise or fall depending on the income and substitution effects. Moreover the real wages for consumption will tend to fall in the importable sector while rising in the non-tradable and exportable sectors.

According to de Melo and Ronald-Horst (1994), the long run effect of standard theory is based on certain assumptions. First, capital stock is mobile in all sectors, thus the impact on non-tradable sector may either be positive or negative depending on the substitution in demand towards the non-tradable sector resulting from negative income effect originating from the worsening of terms of trade. As a result of this substitution, wages will decrease relative to all goods. Also, as there is predominant labour reallocation towards the more capital intensive sector, there will also be a fall in aggregate labour demand (de Melo and Ronald-Horst, 1994). The theory brings to the fore the fact that improvement in terms of trade will come from the increase in export price, but this may not be the case in long run where there is an increase in non-tradable production. The effects of an increase in tariffs is the same as that of an increase in the import price in the country, except there is less of the negative income effect because the government is able to keep tariff revenue. On the other, hand there will be an increase in employment in the non-tradable sector but this is associated with a decline in real production wage. 
Moreover, the argument that growth of trade in the manufacturing sector will hurt unskilled labour in developing countries is derived from the Heckscher-Ohlin-Samuelson-Stopler Theory. The theory clearly shows that the domestic labour supply conditions will determine the relative price and wages. Hence relative wages for skilled and the price for skilled manufactured goods is higher in the South than in North. Reducing trade barriers leads to a fall in the relative price of labour intensive manufactures in North and to a fall in the relative price of skill intensive manufacture in the South (Ghose, 2004). As a result, each country specializes in the production of goods in which they have a comparative advantage.

Neoclassical theory also explains the link of trade reforms and employment. It discusses the link of trade reforms and employment in the short run and long run. According to Hoekman et al 2005, trade reforms aimed at integrating the economy in the global market may not have a long term effect on employment, although it might be accompanied by labour and other market reforms. They argue that in the long run, the labour market will clear in the absence of distortions, with the equilibrium wage being determined by the intersection of demand and supply (Hoekman et al, 2005).

According to Davies (2000), liberalization is associated with changes in industry conditions; hence economic adjustment influences wages, profits, altering income distribution. Haouas et al (2005) found that the wages on the exportable sectors such as textile are higher compared to importable sectors however the relative difference decline over time. Sarris (1990) analyzed labour market in one of two ways. First, he set nominal wages of various employments at fixed values and derived the short run demand for labour. Second, labour market adjustments apply equilibrium-clearing of the labour market independently for each employments type by varying the nominal wages so as to equate labour demand with supply (Sarris, 1990). Thus in a model where prices for the commodity are free to clear their markets, the application of equilibrium-clearing will imply that real wages varies, because prices of the commodity varies also in the face of rigid nominal wages. The other approach leads to relatively steady real wages. The difference is that labour market behavior entails taking into account differences in model behaviour while dealing with the same issue and this has been the subject of many discussion.

\section{Theoretical Model}

In achieving the basic objective of this paper, Njikam (2009) model is adopted to analyze the relationship between trade liberalization and employment in Tanzania. The Cobb-Douglas Production function in the following format is adopted.

$$
q_{i}=A^{\lambda} K_{i}^{\alpha} L_{i}^{\beta}
$$

where $A^{\lambda}$ represent technological efficiency index, Q represent output, $\mathrm{K}$ represent Capital stock, $\mathrm{L}$ represent Labour, $\alpha$ and $\beta$ signify capital and labour factor inputs share coefficients while $\lambda$ speed up the efficiency of production by allowing factors changing. As a point of departure from this model employment is assumed mobile within different sectors. Hence a profit maximizing firm employs capital up to the point where marginal revenue product of capital is equal to user costs $\left(\mathrm{MRP}_{\mathrm{K}}=\mathrm{Z}\right)$, and marginal revenue product of labour is equal to wage $\left(\mathrm{MRP}_{\mathrm{L}}=\mathrm{W}\right)$

In order to eliminate capital in the specification of firm output, equation (9) is solved simultaneously hence the following expression

$$
q_{i}=A^{\lambda}\left(\alpha L i / \beta^{\times w / z}\right)^{\alpha} L
$$

Where $\mathrm{q}$ is output, $\mathrm{L}$, total employment, $\mathrm{Z}$ user costs, other variables are defined as above.

By applying the natural logarithm (10), becomes firm and industry demand for Labour which is a derived demand becomes:

$$
L n L_{i}=q_{0}+q_{1} \operatorname{Ln}\left(\frac{w}{z}\right) q_{2} \operatorname{Ln} q_{i}
$$

Where $q_{0}=-\left(\frac{\lambda \operatorname{In} A+\alpha \operatorname{In} \alpha-\alpha \operatorname{In} \beta}{\alpha+\beta}\right), q_{1}=-\alpha(\alpha+\beta), q_{2}=\frac{1}{(\alpha+\beta)}$

Theoretically, demand for Labour is negatively related to technology while positive related to output. Hence more improvement in technology reduces the demand for unskilled Labour.

Equation (11), assumes that the impact of technology in different industries is the same and uniform, but empirical evidences show that technology is determined by trade patterns. Thus, as stated by Njikam (2009) "technology depends on import penetration, domestic industry protection and export orientation". Thus if technology is substituted in (11), the empirical equation is stated 


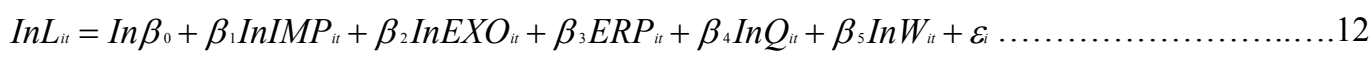

The wage equation is derived using the same procedures adopted in deriving employment model. However wage is defined by the inverse labour supply function, other factors include efficiency wage. In the wage model, the degree of employee market and foreign competition are regarded as key factors in wage setting. To analyze these variables, the model introduces trade share which is captured by import penetration and export intensity. The empirical equation is

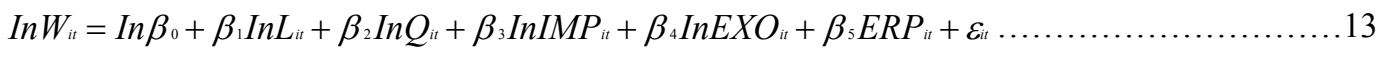

$\beta_{0}$ denotes the intercept term, $\mathrm{L}_{\mathrm{it}}$ and $\mathrm{W}_{\mathrm{it}}$ represent total employment and total wage of textile industry (i) in time period (t) respectively, $\mathrm{Q}_{\mathrm{it}}$ is textile and clothing output, ERP is effective rate of protection (Tariff), EXO is the export intensity, IMP is the import penetration and $\varepsilon i t$ is stochastic error term assumed to be purely random. $\beta_{1}, \beta_{2}$, $\beta_{3}, \beta_{4}, \beta_{5}$, are unknown slope parameters to be estimated. With the exception of ERP all variables are transformed by taking natural logs because ERP is already measured as a rate.

In principle, it is important to test the order of integration of each variable in a model, to establish whether it is non-stationary and how many times the variable needs to be differenced to derive stationary series. There are several ways of testing for the presence of unit root. For the case of this study, emphasis is on the Augmented Dickey-Fuller (ADF). Philip and Perron (1988), propose a non parametric method of controlling for higher order serial correlation in a series. Contrary to ADF, Philip Perron test makes a correction to the t-statistic of the dependent variables in the autoregressive process to account for the serial correlation in random term. As with the ADF test, one has to specify whether to include a constant and linear trend, or neither in the test regression. For the PP test, the truncation lag q for the Newey-West correction is specified which is the number of periods of serial correlation to include in the analysis.

\section{Data Sources and Empirical Results 4.1 Data Sources}

An econometric analysis is carried out to analyze the effects of trade liberalization on employment and wages in the textile and clothing industry of Tanzania. Data is drawn from different documents of industries including annual reports, magazines and their website. Other sources are the Tanzanian Cotton Board, the Bank of Tanzania, Tanzanian Chamber of Commerce, Industry and Agriculture, Board of External Trade (B.E.T), Consortium Tanzania Industries, National Bureau of Statistics, Ministry of Industry, Trade and Marketing and Ministry of Agriculture.

Summary statistics of variables used for analysis is presented in Table 1. All variables except labour seem to follow a normal distribution at both $5 \%$ and $1 \%$ significance level as explained by Jarque-Bera test. According to the Jargue-Bera test, the higher the statistics, the higher the log likelihood that variables are normally distributed. The dependent variables are employment and wages in which the average employment in textile is about 10.20 per cent of employees with a standard deviation of 0.53 percent. The average wage in textile industry is 8.38 per cent of total wage in the industry with standard deviation of 1.69 per cent. This implies that most of textile and clothing industry workers earn about 1.69 per cent of total wage as earnings. The average import penetration is -0.15 with a standard deviation of 1.04. The export intensity has the value of 0.55 percent on the average and 2.12 as standard deviation. The average effective rate of protection in textile industry is 11.16 percent of total protection in textile industry with the standard deviation of 12.11 percent

\subsection{Empirical Results}

The second aspect of econometric analysis is to examine the integration order of each variable used in the empirical models. As a necessary but not sufficient condition for co- integration is that each of the variables must be integrated of the same order and the order of integration must be greater than zero. To achieve this, ADF unit root tests of stationarity is applied as shown in Table 2. The ADF controls for possible serial correlation in error terms by adding the lagged difference terms of the regressand. The asymptotic distributions of the two tests are the same. The figures show that each series is first difference stationary at one percent using ADF test, these results are impressive hence ADF test is used for co-integration Test.

\subsubsection{Testing for Co-integration using Johansen approach}

The main theoretical argument of co-integration analysis is that even if individual variable is non-stationary, the group of variables may drift together. This implies that a linear combination of two or more such variables (time series) can be stationary. As shown in Table 2, since variables are integrated at the same order, there is the need to test for co-integration relationships using Johansen approach. This approach is selected because the Engle and Granger two step procedure conceals information on the coefficients of the explanatory variables in the cointegrating vector, hence makes the approach inappropriate in many cases including this study. The results using 
this approach are found to be sensitive to the lag length used. The Akaike information criterion is used in selecting lag length to be included in the estimation. Cointegration tests of the models assume quadratic deterministic trend in data. Both maximum eigenvalue test and the trace results indicate the existence of a unique co integrating vector between test variables for both employment and wage equations.

In Table 3, the first row tests the hypothesis of no cointegration, the second row tests the hypothesis of one cointegration, and the same applied to the remaining rows against the alternative hypothesis. The normalized cointegrating equation of employment reveals that in the long-run, export intensity has an insignificant positive impact on employment, while the effective rate of protection also has an insignificant impact on demand for labour. Only import penetration has a significant negative impact on employment. These results provide evidence to justify the fact that trade liberalization has a minimal positive impact on employment. Output variable also contribute positively to the employment creation, which is in support of Mkenda (2005). The normalized results of wage equation show that in long run, import concentration has a significant negative impact on wage, compared to export intensity that has an insignificant positive impact on wage. The result is justified as labour is less paid and becomes the major victims and hence likely to remain poor with trade reforms in Tanzania.

The existence of cointegration allows for derivation of the error-correction model from the cointegrating equations by including the lagged error-correction term, hence the long-run information lost through differencing are captured. To be theoretically meaningful the coefficient of the error term should be negative and range between zero and one in absolute term, this ensures the equilibrium error term is meaningful over time in the system. The error-correction term to be estimated stands for the short-run to long-run adjustment equilibrium trends. The next step is to examine the error correction model.

\subsubsection{Vector Error Correction Modeling (VECM)}

Since there is co-integration among dependent variables and its fundamentals, an error correction model has to be estimated by incorporating the lagged error correction term in the set of regressors. The error correction term is the residual from the static long run regression and it joins the set of differenced non-stationary variables to be estimated to capture both short run and long run dynamics. Before estimating the VECM, the variables in co integrated equations are considered as endogenous in the Vector Autoregressive (VAR) model. The model makes use of both differenced data and lagged differenced data of the chosen variables in a VAR model.

Using employment equation, diagnostic tests performed on various orders of the error correction model indicate that the model has negative sign. Various cases such as autocorrelation problem, heteroscedasticity and normality are tested. In addition, the magnitude of the coefficient of error correction term lies between zero and one. This shows that 14 per cent of the short run disequilibrium adjusts to the long run equilibrium each year and also indicate that the speed of employment to converge to the long run equilibrium point is slow. Generally, the estimated coefficients for employment equation in terms of sign and magnitude are significant and meet apriori expectation. The results are good enough to be used as the basis for analysis of the effects of trade liberalization on textile and clothing industry employment.

In terms of wage equation, diagnostic tests on the error correction model indicate that the model does not conform to the apriori expectation that requires the coefficient of the error term to be negative and range between zero to one in absolute term. The positive sign of error correction term implies that an disequilibrium in wage model may not converge to equilibrium in the long run. This is contrary to the efficiency wage and subsistence wage theories. The reason that can be adduced to this finding is the presence of labour union in the Tanzanian textile industry that constitute element of wage rigidity.

\subsubsection{Variance Decomposition}

This gives information about the relative importance of changes in the value of each variable in the VAR. It also provides the proportion of "the movements in the dependent variables that are due to their 'own' shock, versus shock to the other variables" (see Olayiwola and Okodua 2009). Furthermore it provides the proportion of movements between dependent variables caused by it and other variables. In the analysis of variance decomposition, a ten year forecasting horizon is employed.

As documented in Tables 5, a one standard deviation shock to labour force in forecast year 4 accounts for $87.23 \%$ of the variation in employment compared to a lower $6.3 \%$ variation in forecast year 10 . During the same year, a one standard deviation shock to output will cause $1.42 \%$ variation in employment but the variation in employment increases to $6.36 \%$. In term of wage, a one standard deviation shock leads to $6.25 \%$ variation in employment and this variation increases to $19.8 \%$ in forecast year 10. In terms of indicators of trade liberalization, a one standard deviation shock to import penetration in year 1 has no impact on variation of employment. In forecast year 4, it 
accounts for $3.51 \%$ variation of employment and the impact on variation of employment increases to $9.20 \%$ in forecast year 10. Export orientation has a very minimal impact on employment, as its one standard deviation shock accounts for only $0.41 \%$ variation in employment in forecast year 4 and only $1.34 \%$ in forecast year 10 . The trend is also the same in terms of effective rate of protection, as a one standard deviation shock accounts for $1.17 \%$ variation in employment in year 4 and $2.89 \%$ in forecast year 10 . From the analysis, there appears to be no significant impact trade liberalization indicators on employment in forecast year 1 , and the impact becomes more significant from period 4 to 10 .

In terms of wage, as documented in Table 6, a one standard deviation shock to import penetration in forecast year 4 accounts for $2.57 \%$ variation in wage. During the same year, a one standard deviation shock to export concentration leads to $1.78 \%$ variation in wage. The effective rate of protection has a minimal impact in wage, as its one standard deviation accounts for a meager $0.45 \%$ variation in wage. In the forecast year 10 , a one standard deviation shock to import penetration accounts for $10.2 \%$ variation in wage. During the same period, the result of one standard deviation shock to exports concentration accounts for $4.4 \%$ variation in wage. The effect of one standard deviation shock to effective rate of protection on variation in wage still remains very insignificant at $0.76 \%$ during the same period. The analysis of variance decomposition of wage model clearly shows that export concentration and import penetration account for more variation in wage compared to effective rate of protection.

\section{Summary and Conclusion}

The purpose of this study is to analyze the effects of trade liberalization on employment performance in the textile and clothing industry in Tanzania. To achieve this objective, econometric models of employment and wages are estimated using cointegration method of analysis. The results of the analysis show that in the long-run, export intensity and import penetration affects demand of labour in the industry. However, the impact of import penetration is stronger than that of export orientation, but the increase in import competition leads to a decline in labour demand. These findings suggest that trade reforms lead to less employment growth in the textile and clothing sector in Tanzania. In term of wage, only import penetration has a significant positive impact on wage, while both effective rate of protection and export concentration have an insignificant impact on wage. Also, export concentration and import penetration account for more variation in wage compared to effective rate of protection in the long run.

In Tanzania, the process of trade reforms should be more gradual in order to reap the benefits of trade reforms in terms of increase in employment and wage in textile and clothing industry. The reforms should go hand in hand with supply side support especially to develop the domestic private sector. Also, in implementing trade reforms, there is need for government to adopt and maintain selective protection within the WTO Agreements.

\section{References}

Agenor P. and J. Aizenman. (1996). Trade liberalization and unemployment. Journal of International Trade and Economic Development 5 (3).

Agricultural Statistics. (1988). The United Republic of Tanzania, Bureau of Statistics, Dar es Salaam, December, 1990

Babbie, E. R, Et al. (2000). Adventures in social research: data analysis using SPSS for Windows 95/98, California: Thousand Oaks.

Barro, R. J. (1991). Economic Growth in a Cross-Section of Countries. Quarterly Journal of Economics, 106: 407-443.

Bank of Tanzania (1981). Tanzania: twenty years of independence 1961-1981 "A review of political and economic performance. Arusha: Tanzania

Bale, M.D. (1976). Estimates of trade displacement costs for U.S. workers. Journal of International Economics, 6 De Cordoba S and Serena J (2004). Trade liberalization and adjustment costs. Available: r0.unctad.org/ditc/tab/events/nama/docs/Adjustment_Cost17Jan_v1.pdf \{June 5, 2008\}

de Melo, J and D. Roland-Holst. (1994). Economy wide costs of protection and labour market rigidities. in M. Connolly and J. de Melo (Eds) The Effects of Protectionism on a Small Country: The Case of Uruguay Washington DC: The World Bank.

de Melo, J. and D. Tarr. (1990). Welfare costs of U.S. quotas in textiles, steel and autos” Review of Economics and Statistics, 72

Economic and Social Research Foundation. (2006) Trade and poverty in Tanzania: missing impacts or linkage. Dar es sallam: Bank of Tanzania. 
Furusawa, T. (1999) Adjustment costs and gradual trade liberalization. Journal of International Eonomics 49, 333-361.

Ghose, A. K. (2000). Trade liberalization and manufacturing employment. International Labour Organization Employment Paper 2000 (3).

Greenaway, D. (1993). Liberalizing foreign trade through rose-tinted glasses. Economic Journal 103.

Harrison, A and Revenga A. (1995) Factor markets and trade policy reform Washington DC: World Bank.

Kee, H.L. and H.T. Hoon. (2005). Trade, capital accumulation and structural unemployment: an empirical study of the singapore economy. Journal of Development Economics, 77.

Kock, N. (1999). A field study of success and failure factors in a synchronous groupware supported process improvement groups. Business Process Management Journal Volume 5, 238 - 254.

Magee, S. P. (1972).The welfare effects of restriction on US trade. Brookings Papers on Economy Activity 3, 645-701

Martin R. and MacIssave D. (1999). Earnings and welfare after downsizing: Central Bank employees in Ecuador. The World Bank Economic Review. Vol. 13, No. 1.

Matusz S.J. and D. Tarr. (1999). "Adjusting to trade policy reform" World Bank Working Paper 2142, World Bank, Washington D.C.

Mbelle A.V. (1988). Foreign exchange and industrial development: a study of Tanzania. unpublished PhD thesis, Gothenburg School of economics and commercial law.

Milner, C. and P. Wright. (1998). Modelling labour market adjustment to trade liberalization in an industrializing economy. Economic Journal 108.

Mkenda, B. (2005). The impact of globalization on Tanzania's labour market: evidence from the manufacturing Sector. Dar es Sallam: Tanzania.

Njikam O. (2009). Trade Reform and Labor Market Adjustment in Cameroon. \{Online\} Available: www.upjoninst.org/entrepriseresearch/cost/workshop/njikam.pdf (February 4, 2009).

Olayiwola, W. K and H. Okodua. (2009). Foreign direct investment, non-oil exports, and economic growth in Nigeria: a causality analysis. Paper presented at Annual Conference of African Econometric Society, Abuja Nigeria.

Raquel, F and Rodrik D. (1991). Resistance to reform: status quo bias in the presence of individual-specific uncertainty. American Economic Review, 81: 1146-1155.

Rutaihwa J. L. and Olayiwola, W. K. (2010). Trade reform and employment performance of textile industry in Tanzania" Covenant Journal of Business and Social Sciences 3 (1\&2).

Shitundu J.M and Mjema G.D. (1995). Industrial trade during the economic recovery programme and some reflection on future prospects" in Msambichaka B (Eds) Beyond structural adjustment programmes in Tanzania: success, failures and new perspectives, Dar es Salaam: Tanzania.

Winters, L.A and Wendy E. T. (1991). Labour Adjustment Costs and British Footwear Protection. Oxford Economic Papers, 43.

World Bank. (1992). Trade policy reforms under adjustment programs. Washington, D.C: World Bank

World Bank. (1984). The real effects of stabilization and structural adjustment policies: analytics and political economy.IMF Staff Working Paper No. 636. 
Table 1. Summary Statistics of Tanzania Textile Industries 1980-2007

\begin{tabular}{|l|l|l|l|l|l|l|}
\hline & LNL & LNIMP & LNEXO & ERP & LNQ & LNW \\
\hline Mean & 10.20102 & -0.159705 & 0.549733 & 11.16393 & 11.17288 & 8.382526 \\
\hline Median & 10.44616 & 0.322423 & 1.369774 & 9.300000 & 11.10831 & 8.515142 \\
\hline Maximum & 10.67037 & 0.904421 & 2.939691 & 33.06000 & 11.89546 & 12.59349 \\
\hline Minimum & 9.089528 & -2.339249 & -2.995732 & -21.69000 & 10.34821 & 5.789960 \\
\hline Std. Dev. & 0.535046 & 1.049301 & 2.129875 & 12.11309 & 0.396361 & 1.690404 \\
\hline Skewness & -1.348366 & -1.069839 & -0.546388 & -0.315261 & 0.052675 & 0.530124 \\
\hline Kurtosis & 2.944829 & 2.658116 & 1.740445 & 3.227622 & 2.441446 & 3.044431 \\
\hline Jarque-Bera & 8.487981 & 5.477625 & 3.244079 & 0.524264 & 0.376928 & 1.313783 \\
\hline Probability & 0.014350 & 0.064647 & 0.197495 & 0.769409 & 0.828230 & 0.518460 \\
\hline
\end{tabular}

Source: computed from the data sourced from Tanzanian Cotton Board, the Bank of Tanzania, Tanzanian Chamber of Commerce, Industry and Agriculture, Board of External Trade (B.E.T), Consortium Tanzania Industries, National Bureau of Statistics, Ministry of Industry, Trade and Marketing and Ministry of Agriculture.

Table 2. Unit Root Test on Annual data (1980-2007)

\begin{tabular}{|c|c|c|c|c|c|c|}
\hline \multicolumn{7}{|c|}{ ADF UNIT ROOT TEST } \\
\hline \multicolumn{2}{|l|}{ Variables } & \multicolumn{3}{|c|}{ ADF value (constant included) } & \multicolumn{2}{|c|}{ ADF value (constant and linear trend included) } \\
\hline & & \multicolumn{2}{|l|}{ Level } & First differenced & Level & First differenced \\
\hline \multicolumn{2}{|l|}{ LNL } & \multicolumn{2}{|l|}{-1.128359} & $-5.712975^{*}$ & -2.077446 & $-5.855750 *$ \\
\hline \multicolumn{2}{|l|}{ LNIMP } & \multicolumn{2}{|l|}{-1.572428} & $-4.327015^{*}$ & -2.216095 & $-4.327015^{*}$ \\
\hline \multicolumn{2}{|l|}{ LNEXO } & \multicolumn{2}{|l|}{0.26337} & $-4.526889 *$ & -1.973715 & $-4.657409^{*}$ \\
\hline \multicolumn{2}{|l|}{ ERP } & \multicolumn{2}{|l|}{-2.282882} & $-6.919416^{*}$ & -2.575282 & $-6.952143 *$ \\
\hline \multicolumn{2}{|l|}{ LNQ } & \multicolumn{2}{|l|}{-0.965309} & $-4.921556^{*}$ & -1.209564 & $-5.961665^{*}$ \\
\hline \multicolumn{2}{|l|}{ LNW } & -3.835184 & & $-8.088510 *$ & $-4.045266^{* *}$ & $-7.981195^{*}$ \\
\hline Critical & $1 \%$ & -3.699871 & & -3.711457 & -4.339330 & -4.356068 \\
\hline Values & $5 \%$ & -2.976263 & & -2.981038 & -3.587527 & -3.595026 \\
\hline & $10 \%$ & -2.627420 & & -2.629906 & -3.229230 & -3.233456 \\
\hline & & & & TRACE TES & & \\
\hline Eigenvalue & & trace static & & 5 per cent critical level & Prob** & Hypothesized No. of CE(s) \\
\hline 0.969808 & & 149.7181 & & 107.3466 & 0.0000 & None ** \\
\hline 0.667125 & & 58.71378 & & 79.34145 & 0.6174 & At most 1 \\
\hline 0.422581 & & 30.11409 & & 55.24578 & 0.9270 & At most 2 \\
\hline 0.323753 & & 15.83523 & & 35.01090 & 0.9174 & At most 3 \\
\hline 0.149798 & & 5.664115 & & 18.39771 & 0.8938 & At most 4 \\
\hline 0.054053 & & 1.444800 & & 3.841466 & 0.2294 & At most 5 \\
\hline & & & & AXIMUM EIGENVAL & UE TEST & \\
\hline Eigenvalue & & Max-EigenSt & & 5 per cent critical level & Prob** $^{* *}$ & Hypothesized No. of CE(s) \\
\hline 0.969808 & & 91.00437 & & 43.41977 & 0.0000 & None $* *$ \\
\hline 0.667125 & & 28.59968 & & 37.16359 & 0.3416 & At most 1 \\
\hline 0.422581 & & 14.27886 & & 30.81507 & 0.9313 & At most 2 \\
\hline 0.323753 & & 10.17112 & & 24.25202 & 0.8944 & At most 3 \\
\hline 0.149798 & & 4.219314 & & 17.14769 & 0.9513 & At most 4 \\
\hline 0.054053 & & 1.444800 & & 3.841466 & 0.2294 & At most 5 \\
\hline Co integrat & coeff & ient normalized on & aployment & (standard error in pare & ntheses) & \\
\hline $\mathrm{L}$ & & $\mathrm{Q}$ & W & IMP & EXO & ERP \\
\hline 1.000000 & & -0.496970 & 0.112282 & -18292.03 & -1350.925 & -168.4577 \\
\hline & & $(-0.01512)$ & $(-0.00641)$ & $(-952.633)$ & $(-109.911)$ & $(-30.0540)$ \\
\hline $\mathrm{W}$ & & $\mathrm{L}$ & $\mathrm{Q}$ & IMP & EXO & ERP \\
\hline 1.000000 & & 8.906152 & 4.426089 & 162911.6 & 12031.55 & 1500.310 \\
\hline & & $(-0.48428)$ & $(-0.19399)$ & $(-8879.04)$ & $(-983.050)$ & $(-264.070)$ \\
\hline
\end{tabular}


Max-eigenvalue test indicates 5 cointegrating eqn(s) at the 0.05 level

* denotes rejection of the hypothesis at the 0.05 level

**MacKinnon-Haug-Michelis (1999) p-values

Source: computed from the data Source: computed from the data sourced from Tanzanian Cotton Board, the Bank of Tanzania, Tanzanian Chamber of Commerce, Industry and Agriculture, Board of External Trade (B.E.T), Consortium Tanzania Industries, National Bureau of Statistics, Ministry of Industry, Trade and Marketing and Ministry of Agriculture.

LN is a logarithm and ADF is the Augmented Dickey Fuller

Asterisk $* * *$ and $* * *$ indicate significance at the $1 \%, 5 \%$ and $10 \%$ significance levels respectively

Table 3. Vector Error Correction Model for Employment, Standard errors in ( ) \& t-statistics in [ ]

\begin{tabular}{|l|l|l|l|l|l|l|}
\hline Variable & $\mathrm{D}(\mathrm{InL})$ & $\mathrm{D}(\mathrm{InQ})$ & $\mathrm{D}(\mathrm{InW})$ & $\mathrm{D}(\mathrm{InIMP})$ & $\mathrm{D}(\mathrm{InEXO})$ & $\mathrm{D}(\mathrm{ERP})$ \\
\hline ECT_1 & 0.142351 & 0.266703 & -0.177249 & $-9.50 \mathrm{E}-06$ & $1.75 \mathrm{E}-05$ & $2.57 \mathrm{E}-06$ \\
\hline & $(0.11467)$ & $(0.22528)$ & $(1.03885)$ & $(3.1 \mathrm{E}-06)$ & $(3.5 \mathrm{E}-05)$ & $(0.00017)$ \\
\hline & {$[1.24144]$} & {$[1.18385]$} & {$[-0.17062]$} & {$[-3.07803]$} & {$[0.49354]$} & {$[0.01515]$} \\
\hline
\end{tabular}

Source: computed from the data analysis

Table 4. Vector Error Correction Model for Wage, Standard errors in ( ) \& t- statistics in [ ]

\begin{tabular}{|l|l|l|l|l|l|l|}
\hline Variable & $\mathrm{D}(\mathrm{InW})$ & $\mathrm{D}(\mathrm{InL})$ & $\mathrm{D}(\mathrm{InQ})$ & $\mathrm{D}(\mathrm{InIMP})$ & $\mathrm{D}(\mathrm{InEXO})$ & $\mathrm{D}(\mathrm{ERP})$ \\
\hline ECT_1 & 0.025939 & 0.020832 & -0.039029 & $-1.39 \mathrm{E}-06$ & $2.56 \mathrm{E}-06$ & $-3.76 \mathrm{E}-07$ \\
\hline & $(0.15203)$ & $(0.01678)$ & $(0.03297)$ & $(4.5 \mathrm{E}-07)$ & $(5.2 \mathrm{E}-06)$ & $(2.5 \mathrm{E}-05)$ \\
\hline & {$[0.17062]$} & {$[1.24144]$} & {$[-1.18385]$} & {$[-3.07803]$} & {$[0.49354]$} & {$[-0.01515]$} \\
\hline
\end{tabular}

Source: Extracted from data analysis

Table 5. Variance Decomposition for Employment

\begin{tabular}{|l|l|l|l|l|l|l|l|}
\hline \multicolumn{7}{|c|}{ Decomposition of Variance for Employment } \\
\hline Period & Std Err & InL & InQ & InW & InIMP & InEXO & ERP \\
\hline 1 & 7508.818 & 100.000 & 0.0000 & 0.0000 & 0.0000 & 0.000 & 0.0000 \\
\hline 4 & 13693.31 & 87.23200 & 1.429090 & 6.232298 & 3.518940 & 0.410925 & 1.176749 \\
\hline 7 & 19390.53 & 73.10679 & 3.867979 & 13.31861 & 6.678686 & 0.902446 & 2.125482 \\
\hline 10 & 25301.98 & 60.31283 & 6.362356 & 19.88188 & 9.203389 & 1.341283 & 2.898269 \\
\hline
\end{tabular}

Cholesky Ordering: InL InQ InW InMP InEXO ER

Source: Data from the appendix Table A5

Table 6.Variance Decomposition for Wage

\begin{tabular}{|l|l|l|l|l|l|l|l|}
\hline \multicolumn{7}{|c|}{ Decomposition of Variance for InW } \\
\hline Period & Std Err & InW & InL & InQ & InIMP & InEXO & ERP \\
\hline 1 & 68028.43 & 100.0000 & 0.000000 & 0.000000 & 0.000000 & 0.000000 & 0.000000 \\
\hline 4 & 94271.17 & 90.23383 & 0.331242 & 4.616795 & 2.577122 & 1.781831 & 0.459181 \\
\hline 7 & 112452.3 & 80.59876 & 0.325773 & 9.595594 & 5.944119 & 3.088558 & 0.447197 \\
\hline 10 & 129036.6 & 68.05954 & 0.280434 & 16.24917 & 10.23624 & 4.410239 & 0.764379 \\
\hline
\end{tabular}

Cholesky Ordering: InW InL InQ InIMP InEXO ERP

Source: Table A5 